\title{
Paroxysmal hemicrania-tic syndrome: a new case report
}

\author{
I Maestrini", A Viganò, G Di Stefano, A Truini, G Cruccu, GL Lenzi, V Di Piero \\ From The European Headache and Migraine Trust International Congress \\ London, UK. 20-23 September 2012
}

\begin{abstract}
Introduction
An association of Paroxysmal Hemicrania (PH) with Trigeminal Neuralgia $(\mathrm{TN})$ was described in eight patients $[1,2]$ and has been called the PH-tic syndrome [3]. Case report. A 52-year-old man presented with a 5-year history of excruciating and burning pain, involving the left ophthalmic trigeminal branch, lasted 30 to 60 seconds, occurred 2 to 5 times a day, without any autonomic sign. Triggering factors included touching, washing face or brushing the teeth. Carbamazepine $(600 \mathrm{mg} /$ day $)$ produced marked improvement. Any attempt to reduce the dose resulted in pain recurrence. While the previous pain was in remission by carbamazepine, he complained of a second type of pain that lasted 15 to 30 minutes and occurred up to 8 times per day. The strictly unilateral pain occurred in the left orbit, forehead, temple, nose and was described as severe and sharp with autonomic signs. There were no triggers. Indomethacin $(150 \mathrm{mg} /$ day $)$ completely resolved attacks. His past medical history was significant for atrial fibrillation, hypertension and glaucoma; neurological examination and blood analysis were normal. Brain magnetic resonance showed silent lacunar infarcts, while magnetic cerebral angiography was normal. Trigeminal reflexes were also normal. In order to assess the possible involvement of the small myelinated and unmyelinated trigeminal fibers, we recorded, using a Nd:YAP laser stimulator, laser evoked potentials (LEPs) after supraorbital stimulation that showed a normality of A-delta and C fibers activation of the affected compared to the normal side. At the time of LEPs the patient was TN and $\mathrm{PH}$ off-indomethacin pain-free.
\end{abstract}

\section{Conclusion}

LEPs study supported the diagnosis of TN idiopathic. It is still debated if the rare association of $\mathrm{TN}$ and $\mathrm{PH}$ is a

$$
\text { Department of Neurology and Psychiatry, 'Sapienza' University of Rome, }
$$$$
\text { Rome, Italy }
$$

new entity or two distinct disease. Further investigations by neuroimaging might be useful to clarify this issue and to better understand the pathophysiology of these entities [4].

Published: 21 February 2013

\section{References}

1. Martinez-Salio A, Porta-Etessam J, Gutérrez-Rivas E: “Chronic Paroxysmal Hemicrania-Tic Syndrome". Headache 2000, 40:682-685.

2. Zuckerman E, Peres MFP, Costa AR: "Chronic paroxysmal hemicrania-Tic syndrome". Neurology 2000, 54:1524-1526.

3. Boes CJ, Matharu MS, Goadsby PJ: "The paroxysmal hemicrania-tic syndrome". Cephalalgia 2003, 23:24-28.

4. Leone M, Bussone G: "Coexistence of TACS and Trigeminal Neuralgia: Pathophysiological Conjectures". Headache 2006, 46:1565-1570.

doi:10.1186/1129-2377-14-S1-P50

Cite this article as: Maestrini et al:: Paroxysmal hemicrania-tic syndrome: a new case report. The Journal of Headache and Pain 2013 14(Suppl 1): P50.

Submit your manuscript to a SpringerOpen ${ }^{\odot}$ journal and benefit from:

- Convenient online submission

- Rigorous peer review

- Immediate publication on acceptance

- Open access: articles freely available online

- High visibility within the field

- Retaining the copyright to your article

Submit your next manuscript at $>$ springeropen.com 